\title{
Covid: Desist Dire Discombobulation! Nothing Novel, Several Subtle Septic Strains Shall Still Surely Surreptitiously Surface
}

\author{
Seun Ayoade* \\ Independent Researcher Alumnus, College of Medicine University of Ibadan, Oyo State, Nigeria \\ *Corresponding author: Seun Ayoade, Independent Researcher Alumnus, College of Medicine University of Ibadan, Oyo \\ State, Nigeria
}

\begin{tabular}{|c|c|}
\hline ARTICLE INFO & ABSTRACT \\
\hline Received: 茂 January 05, 2021 & $\begin{array}{l}\text { Citation: Seun Ayoade. Covid: Desist Dire Discombobulation! Nothing Novel, Several } \\
\text { Subtle Septic Strains Shall Still Surely Surreptitiously Surface. Biomed I Sci \& Tech Res }\end{array}$ \\
\hline
\end{tabular}

Published: 幽 January 25, 2021

33(3)-2021. BJSTR. MS.ID.005390.

\section{Opinion}

Table 1.

\begin{tabular}{|c|c|}
\hline Malady & Number of Causative Virus Strains \\
\hline Common Cold & 200 \\
\hline Chickenpox & 22 \\
\hline Hanta Fever & 20 \\
\hline AIDS & 60 \\
\hline Yellow Fever & 53 \\
\hline Ebola & 5 \\
\hline Dengue Fever & 4 \\
\hline Hepatitis & 5 \\
\hline Herpes & 8 \\
\hline Rubella & 4 \\
\hline Influenza & 4 \\
\hline Mumps & 4 \\
\hline Polio & 3 \\
\hline
\end{tabular}

There's been a lot of hubbub in the media about the emergence of new corona virus strains. I am no prophet of doom, but I predict that even more covid virus strains will appear, including recombinant strains. To deny this is to bury one's head in the sand and ignore the accumulated knowledge of microbiologists. Covid cannot be an exception to other viral diseases that plague humanity, all which come in multiple strains. Nature is relentless and will run its course, even at the microscopic level. I also doubt that the current vaccination drive will completely get us out of the woods. I predict that in spite of vaccination covid will not be completely eradicated this year or anytime in the near future. Covid infection rates will at best be greatly curbed, lockdowns will cease and life will return to normal for most people. Thereafter covid will come and go with varying intensities every year or every other year or every five years etc. There is but one feather in vaccination's cap-smallpox. And there are those that argue that smallpox, after thousands of years, had run its course and was already on its way out. Below are a few viral infectious diseases affecting humans and the number of attendant strains [1-5] (Table 1).

\section{References}

1. Arij Limam (2020) What are mutated strains of COVID-19 and are they important?

2. (2020) The six strains of SARS-CoV-2. Science Daily.

3. (2019) What's Causing My Cold?

4. Gisela Enders (1996) Medical Microbiology. ( $4^{\text {th }}$ Edn.) In Samuel Baron (Eds.).p. 56.

5. Eng Eong Ooi, Duane J Gubler (2011) Tropical Infectious Diseases: Principles, Pathogens and Practice ( $3^{\text {rd }}$ Edn.). Dengue and Dengue Hemorrhagic Fever pp. 504-510. 
ISSN: 2574-1241

DOI: 10.26717/BJSTR.2021.33.005390

Seun Ayoade. Biomed J Sci \& Tech Res

(c) (P) This work is licensed under Creative

Submission Link: https://biomedres.us/submit-manuscript.php

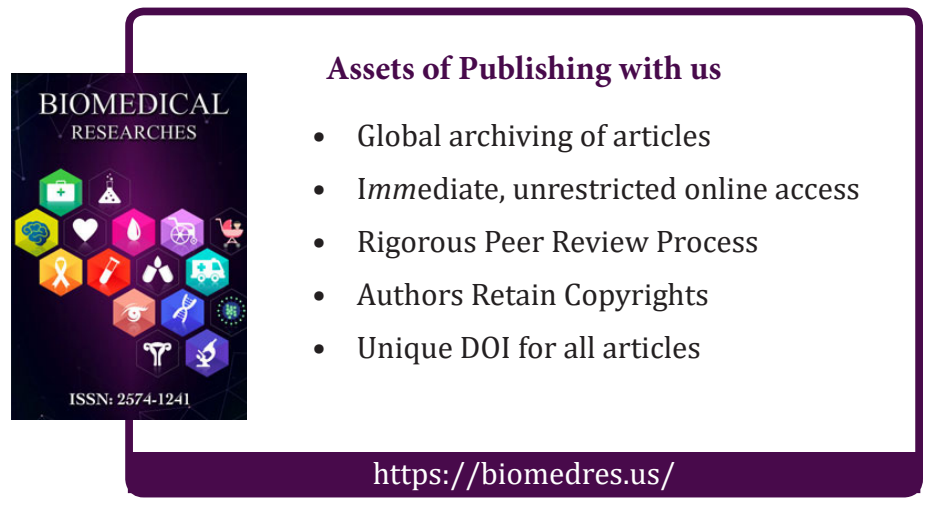

